\title{
PERBEDAAN DAYA HAMBAT OBAT ANESTESI LOKAL LIDOCAINE 2\% DAN ARTICAINE $4 \%$ TERHADAP PERTUMBUHAN BAKTERI Porphyromonas gingivalis SECARA IN VITRO
}

\author{
Fairuza Muharammy ${ }^{1}$, Rizanda Machmud ${ }^{2}$, Surya Nelis ${ }^{1}$
}

\begin{abstract}
Porphyromonas gingivalis is a gram-negative anaerobic bacteria which is an oral normal microflora located in subgingival area.This bacteria can cause inflamation and delayed wound healing after dental invasive procedures. Lidocaine $2 \%$ and articaine $4 \%$ are the most used anaesthetic agents in dentistry. Both of these agents have been studied for having antibacterial effect in certain concentrations. This will open the possibility of using local anaesthetic agents as antibacterial agent in dental invasive procedures to prevent infection after procedures. The purpose of this study is to analyze the difference inhibition of local anaesthetics drug lidocaine $2 \%$ and articaine $4 \%$ on the growth of Porphyromonas gingivalis bacteria in vitro. The study subject was pure culture of Porphyromonas gingivalis ATCC 33277 divided by two group, one group with lidocaine $2 \%$ and other with articaine 4\%. This study was experimental laboratory with post test only control group design. The mean of inhibitions were obtained by measuring inhibition zone formed around paper discs with caliper in milimeter scale. The result showed Inhibition rate lidocaine $2 \%$ had greater rate than articaine $4 \%$ in inhibiting the growth of Porphyromonas gingivalis bacteria in vitro.The conclusion was lidocaine $2 \%$ was more effective than articaine $4 \%$ in inhibiting the growth of Porphyromonas gingivalis bacteria in vitro.
\end{abstract}

Keywords: Antibacteria, Local anaesthetic, Lidocaine 2\%, Articaine 4\%, Porphyromonas gingivalis

Affiliasi penulis : 1. Fakultas Kedokteran Gigi

Universitas Andalas, 2. Fakultas Kedokteran Universitas Andalas

Korespondensi: Fairuza Muharammy :email: muharammy@gmail.com Telp: 085355975202

\section{PENDAHULUAN}

Prosedur dental yang invasif sering diikuti dengan berbagai macam komplikasi. Komplikasi yang terjadi dapat disebabkan oleh berbagai macam faktor dan tidak semua dapat dihindari. Komplikasi dental dapat dibagi menurut wilayahnya, komplikasi lokal terjadi pada wilayah prosedur dan dapat terjadi saat dan setelah prosedur sedangkan komplikasi sistemik umumnya terlihat beberapa saat setelah prosedur selesai

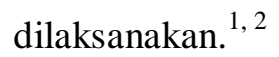

Komplikasi yang sering terjadi pasca prosedur dental adalah infeksi yang menyebabkan pembengkakan dan rasa sakit bagi pasien. Infeksi pasca prosedur terjadi karena adanya manipulasi permukaan epitel rongga mulut. Manipulasi ini mengganggu fungsi epitel sebagai barrier fisik dan memudahkan invasi mikroorganisme patogen ke jaringan dibawah epitel serta aliran darah. Kontaminasi mikroorganisme yang lebih jauh dapat menyebabkan efek sistemik seperti bakteremia dan fokal infeksi. ${ }^{2,3}$ 
Insiden prosedur dental yang diikuti bakteremia telah banyak diteliti. Bakteremia merupakan kondisi terdapatnya bakteri di dalam aliran darah. Angka kejadian bakteremia yang diobsevasi pada pasien pasca prosedur dental invasif sangat tinggi, seperti pada prosedur ekstraksi (100\%), dental scaling (70\%), bedah pengangkatan molar ketiga (55\%), tonsilektomi bilateral (55\%), perawatan endodontik (20\%). Eliminasi mikroorganisme dari pembuluh darah atau periode non bakteremik secara alami terjadi cukup cepat yaitu 10 menit setelah kontaminasi, meskipun begitu, bakteremia tetap memiliki potensi bahaya bagi pasien dengan kondisi jantung dan dapat menjadi predisposisi terjadinya infective endocarditis . ${ }^{3,4}$

Bakteri anaerob gram negatif Porphyromonas gingivalis merupakan bakteri yang berada pada plak subgingiva. Bakteri ini tergolong dalam red complex bersama dengan bakteri Tannerella forsythia, dan Treponema denticola. Kompleks bakteri ini berhubungan erat dengan penyakit periodontal yang ditunjukkan dari peningkatan pembentukan lesi periodontitis secara signifikan pada infeksi campuran ketiga bakteri ini dibandingkan dengan monoinfeksi. Porphyromonas gingivalis juga berpotensi mempengaruhi proses penyembuhan luka pasca bedah. Hal ini terjadi melalui mekanisme yang terdiri atas peningkatan apoptosis, pengurangan migrasi sel dan perlambatan proliferasi sel. Enzim proteolytic yang diproduksi bakteri Porphyromonas gingivalis merupakan faktor virulensinya. ${ }^{5-7}$

Inflamasi lokal dan lamanya proses penyembuhan yang diakibatkan infeksi Porphyromonas gingivalis dapat mempermudah terjadinya infeksi sekunder oleh bakteri lain. Porphyromonas gingivalis juga dapat menyebabkan perubahan vaskular yang berakibat meningkatnya insiden dan keparahan intermittent bacteremia karena trauma gingiva. Porphyromonas gingivalis yang mengkontaminasi aliran darah dapat melekat dan menginvasi endotel serta sel otot halus pada arteri koroner. Kontaminasi bakteri ini pada aliran darah dapat menyebabkan penggumpalan platelet yang menghasilkan intravascular clot $^{3,8}$

Tingginya angka bakteremia pada prosedur dental menuntut dokter gigi untuk menggunakan tindakan profilaksis. Antibiotik profilaksis berupa amoxycillin $2 \mathrm{~g}$ atau clindamycin $600 \mathrm{~g}$ digunakan secara umum sebagai standar klinis pada prosedur invasif terutama bila pasien tergolong beresiko tinggi. Penggunaan 
antibiotik profilaksis masih diragukan efisiensi, resiko kesehatan dan costeffectivitynya. Antibiotik beresiko menyebabkan reaksi alergi berupa syok anafilaktik, selain itu indikasi dan dosis penggunaannya harus diperhatikan karena pemakaian antibiotik yang berulang dengan dosis yang berlebihan dapat menyebabkan resitensi bakteri. ${ }^{9,10}$

Anestesi lokal merupakan agen farmakologik disamping antibiotik yang digunakan dalam tindakan invasif. Bahan ini dibutuhkan untuk menghilangkan rasa sakit maupun sensasi lainnya pada area spesifik di mulut untuk durasi yang singkat. Bahan ini umumnya ditambah kandungan bahan aktif berupa vasokonstriktor seperti epinephrine untuk memperpanjang durasi dan mengontrol pendarahan saat prosedur. ${ }^{11,12}$

Anestesi lokal dibagi atas dua golongan berdasarkan struktur kimia dan rantainya yaitu golongan ester dan golongan amida. Bahan anestesi golongan ester berupa cocaine, procaine, chloroprocaine dan tetracaine di metabolisme secara hidrolisis di plasma oleh enzim pseudocholinesterase. Anestesi lokal golongan amida yaitu lidocaine, mepivacaine, bupivacaine, etidocaine, dan prilocaine di metabolisme oleh enzim mikrosomal yang terletak di hati. Golongan amida dewasa ini lebih sering digunakan dalam kedokteran gigi karena resiko alerginya lebih rendah dibanding golongan ester. 11,12

Lidocaine merupakan bahan anestesi yang mulai digunakan pada tahun 1948. Bahan ini merupakan bahan anestesi lokal golongan amida pertama yang menggantikan kepopuleran bahan anestesi lokal golongan ester procaine dalam kegunaannya di bidang kedokteran gigi. Persentase dokter gigi menggunakan bahan ini yaitu 41,93\%, menjadikan lidocaine hcl 2\% sebagai bahan anestesi yang paling sering digunakan dalam pencabutan gigi,. Hal ini disebabkan onsetnya yang cepat, lebih stabil, serta tingkat toksisitas dan alergenik yang rendah dan dibanding bahan anestesi lainnya. ${ }^{12,13}$

Articaine merupakan bahan anestesi lokal yang kedua paling sering digunakan dalam kedokteran gigi (persentase 9,67\%) dan merupakan satusatunya anestesi lokal golongan amida yang mengandung cincin thiophene. Kandungannya yang unik menyebabkan articaine mengalami biotransformasi di dua tempat yaitu di plasma dan di hati. Bahan ini mulai digunakan secara klinis pada tahun 1976 di Jerman. Articaine secara umum digunakan dalam konsentrasi $4 \%$ dengan epinefrin, 
penggunaan dibawah dosis tersebut mengurangi keefektifitasan onset dan durasi bahan ini. ${ }^{13-15}$

Penggunaan lidocaine 2\% dan articaine $4 \%$ yang menjadi pilihan utama selain dianggap lebih efektif juga dikarenakan ketersediaannya lebih banyak dan harganya yang murah. Indikasi , durasi, mekanisme dan onset kedua bahan ini pun serupa, namun articaine dapat lebih mudah menyebar ke jaringan karena kandungan cicin thiophene meningkatkan liposolubilitynya. Struktur molekul articaine memiliki ujung lypophilic dan hydrophilic yang dihubungkan dengan rantai hidrokarbon. Articaine lebih cepat dimetabolisme tubuh dengan paruh waktu 60 menit dibandingkan dengan lidocaine yang paruh waktunya 90-120 menit. Lidocaine yang hanya dimetabolisme di satu tempat juga dapat terhambat metabolismenya apabila pasien memiliki gangguan fungsi hati. Metabolisme articaine yang lebih cepat membuat bahan ini memiliki resiko toksisitas yang lebih rendah dan aman digunakan pada pasien yang menderita epilepsi. ${ }^{13-16}$

Bahan anestesi telah diteliti memiliki efek antimikrobial. Parr dkk seperti yang dikutip Johnson SM dkk menyatakan bahwa aplikasi penggunaan anestesi lokal yang lebih luas dapat disarankan dalam perawatan infeksi luka bedah. Bahan anestesi lokal amida seperti bupivacaine, prilokain, ropivacaine dan lidocaine pada konsentrasi $2 \%$ terbukti menghambat pertumbuhan berbagai mikroba patogen seperti Escherichia coli, S. aureus, S. epidermidis, Streptococcus pneumoniae, S. pyogenes, Enterococcus faecalis, Bacillus cereus, dan Candida albicans. Penelitian daya hambat terhadap bakteri nosokomial (P. Aeruginosa, E.coli, $P$. Mirabilis, S. Aureus, S. Marcescens) juga menyimpulkan bahwa articaine dan lidocaine tercatat memiliki efek bakterisidal dan bakteriostatik pada konsentrasi tertentu. ${ }^{17,18}$

Mekanisme aksi bahan anestesi terhadap bakteri terjadi melalui lisis membran sel yang menyebabkan kebocoran komponen intraselular, aktifitas dehidogenase dan meningkatkan permeabilitas dinding sel. Kandungan pada lidocaine berupa membranestabilizing property juga berpengaruh terhadap aktifitas mikroba yang dapat menekan pertumbuhan mikroorganisme bakteri. Semakin lama waktu eksposur bahan anestesi lokal terhadap bakteri maka semakin besar pula daya hambatnya terhadap pertumbuhan bakteri. $^{17,18}$ 
Berdasarkan berbagai hasil penelitian tersebut, peneliti tertarik untuk meneliti perbedaan daya hambat pada bahan anestesi lokal lidocaine dan articaine terhadap salah satu bakteri rongga mulut yang menyebabkan infeksi dan menghambat penyembuhan luka pasca prosedur dental, yaitu Porphyromonas gingivalis. Hal ini membuka kemungkinan potensi penggunaan bahan anestesi lokal sebagai agen antimikrobial dalam tindakan perawatan gigi invasif disamping antibiotik profilaksis untuk mencegah terjadinya infeksi.

\section{METODE}

Penelitian ini adalah eksperimental laboratoris dengan rancangan penelitian post test only control group design, yaitu melakukan pengamatan atau pengukuran setelah perlakuan.

Penelitian dilakukan di Laboratorium Mikrobiologi RSUP. DR. M. Djamil Padang pada bulan Maret 2017. Sampel dalam penelitian ini adalah biakan murni bakteri Porphyromonas gingivalis ATCC 33277 yang diperoleh dari Oral Biology Laboratorium Fakultas Kedokteran Gigi Universitas Indonesia.

Nutrien Agar (NA) sebanyak 1 gram sebagai media peremajaan bakteri dilarutkan dengan $50 \mathrm{ml}$ akuades menggunakan tabung Erlenmeyer dan ditutup dengan kapas, dihomogenkan, disterilkan dalam autoclave kemudian dimasukkan dalam cawan petri dan dibiarkan hingga mengeras.

$$
\text { Agar Muller-Hinton }
$$
sebanyak 6,8 gram sebagai media uji dilarutkan dengan $200 \mathrm{ml}$ akuades menggunakan tabung Erlenmeyer dan ditutup dengan kapas, dihomogenkan, disterilkan dalam autoclave kemudian dimasukkan dalam cawan petri dan dibiarkan hingga mengeras.

Sediaan bakteri Porphyromonas gingivalis yang disimpan di media agar diambil dengan jarum ose steril, lalu ditanamkan pada media agar miring dengan cara menggores, ditutup dengan kapas dan aluminium foil kemudian diinkubasi dalam inkubator pada suhu $37^{\circ}$ C selama 1 x 24 jam. Untuk membuat suspensi, bakteri yang telah diinkubasi diambil koloninya dari media agar miring dengan menggunakan jarum ose steril. Pindahkan pertumbuhan (koloni) tersebut ke sebuah tabung berisi $\mathrm{NaCl} \quad 0,9 \%$ sampai kekeruhannya sama dengan standar McFarland. Pengaturan kekeruhan suspensi yang tepat penting untuk memastikan hasil pertumbuhan yang merata atau hampir merata. Suspensi diambil menggunakan pipet tetes, kemudian teteskan pada cawan 
petri, setelah itu dilakukan usapan menggunakan batang penyebar ke seluruh permukaan cawan petri yang berisi MHA secara merata. Biarkan inokulum mengering selama beberapa menit pada suhu ruangan dengan cawan tertutup.

Metode pengujian yang digunakan yaitu metode difusi (disc diffusion Kirby and Bauer) menggunakan kertas cakram. Menyiapkan 34 kertas cakram yang direndam di dalam 2 wadah kecil berbeda yang masing-masing berisi lidocaine $2 \%$ dan articaine $4 \%$. Setiap tabung terdapat 17 kertas cakram kemudian diletakkan disetiap area pada cawan petri. Semua cawan ditutup dan dimasukkan kedalam anaerobic jar dan gaspack. Setelah 24 jam, cawan petri yang telah diinkubasi dikeluarkan dari inkubator untuk melihat zona hambat yang terbentuk, kemudian diukur menggunakan jangka sorong digital.

\section{HASIL}

Tabel 5.1. Diamater zona bening pada sampel perlakuan dengan lidocaine $2 \%$ dan articaine $4 \%$.

\begin{tabular}{lcccc}
\hline Kelompok & $\mathbf{n}$ & $\begin{array}{c}\text { Rata- } \\
\text { rata }\end{array}$ & min & $\max$ \\
\hline Lidokain 2\% & 17 & 19,06 & 17,94 & 20,21 \\
Articaine 2\% & 17 & 14,09 & 13,19 & 15,02 \\
& & & & \\
\hline
\end{tabular}

Berdasarkan tabel 5.1 dapat dilihat bahwa nilai rata-rata diamater zona bening pada sampel dengan lidocaine $2 \%$ adalah 19,06 $\mathrm{mm}$ dan articaine 4\% adalah $14,09 \mathrm{~mm}$.

Analisis bivariat yang digunakan pada penelitian ini adalah uji Independent Sample T-test. Uji ini dilakukan untuk mengetahui perbedaan diamater zona bening pada sampel antara masingmasing dua kelompok perlakuan, yaitu kelompok dengan lidocaine $2 \%$ dan articaine $4 \%$.

Sebelum melakukan uji analisis statistik, terlebih dahulu dilakukan uji normalitas pada masing-masing kelompok sampel dengan menggunakan uji statistik Shapiro-Wilk untuk melihat data penelitian berdistribusi normal atau tidak. Uji normalitas menunjukkan nilai p>0,05 yang berarti data penelitian ini berdistribusi normal.

Tabel 5.2 Perbedaan Diameter Zona Bening Pada Sampel Perlakuan dengan Lidocaine $2 \%$ dan Articaine

\begin{tabular}{ccccc}
$4 \%$ & & & \\
\hline Kelompok & $\mathbf{N}$ & Rerata \pm SD & P \\
\hline \multirow{2}{*}{ Lidocaine 2\% } & 17 & $19,06 \pm 0,78$ & 0,000 \\
Articaine 4\% & 17 & $14,09 \pm 0,47$ & \\
\hline
\end{tabular}

*signifikan $p<0,05$

Berdasarkan tabel 5.3 diperoleh nilai $\mathrm{p}=0,000$. Signifikan yang digunakan adalah $\mathrm{p}<0,05$ maka dapat disimpulkan bahwa terdapat perbedaan yang bermakna terhadap daya hambat obat anestesi Lidocaine 2\% dan Articaine 4\% terhadap pertumbuhan bakteri Porphyromonas gingivalis secara in vitro. 


\section{PEMBAHASAN}

Hasil penelitian ini menunjukkan bahwa rata-rata zona hambat pada sampel perlakuan dengan lidocaine 2\% adalah 19,06 mm, dan articaine 4\% adalah 14,09 $\mathrm{mm}$. Dilihat dari hasil pengukuran zona hambat, bahan uji yang membentuk zona hambat rata-rata lebih besar adalah obat anestesi berupa lidocaine 2\%. Menurut Greenwood, respon hambat bakteri dapat di klasifikasikan sebagaimana dalam Tabel 6.1. ${ }^{26}$

\begin{tabular}{|c|c|}
\hline Diameter Zona Bening & $\begin{array}{c}\text { Respon Hambatan } \\
\text { Pertumbuhan }\end{array}$ \\
\hline$>20 \mathrm{~mm}$ & Kuat \\
\hline $16-20 \mathrm{~mm}$ & Sedang \\
\hline $10-15 \mathrm{~mm}$ & Lemah \\
\hline$<10 \mathrm{~mm}$ & Tidak Efektif \\
\hline
\end{tabular}

Rata-rata zona bening yang dihasilkan apabila dikonversikan ke dalam klasifikasi respon hambatan pertumbuhan bakteri menurut Greenwood, lidocaine $2 \%$ termasuk dalam klasifikasi sedang, dan articaine 4\% termasuk dalam klasifikasi lemah. Tabel ini menunjukkan bahwa daya hambat lidocaine $2 \%$ berada satu tingkat lebih tinggi dibanding articaine 4\% yang menjadikan lidocaine 2\% lebih efektif dalam menghambat pertumbuhan Porphyromonas gingivalis dibandingkan dengan articaine $4 \%$. Perbedaan efektifitas tersebut dapat terjadi karena perbedaan susunan kimia pada kedua bahan dimana lidokain memiliki kandungan membrane-stabilizing property yang berpengaruh terhadap aktifitas mikroba yang dapat menekan pertumbuhan mikroorganisme bakteri. $^{18,26}$

Penelitian sebelumnya oleh Kaya K menggunakan lima bakteri aerob yang menyebabkan infeksi nosokomial yaitu Pseudomonas aeruginosa, Escherichia coli, Proteus mirabillis, Staphylococcus aureus, dan Serratia marcescens terhadap berbagai konsentrasi artikain dan lidokain. Pada konsentrasi 1\%, artikain dapat menghambat semua bakteri uji, sedangkan pada lidokain tetap ditemukan pertumbuhan Pseudomonas aeruginosa dan Staphylococcus aureus dalam konsentrasi yang sama. ${ }^{18,26}$

Perbedaan hasil ini dapat diakibatkan karena bedanya bakteri yang digunakan dalam penelitian. Penelitian Kaya K menggunakan bakteri aerob, sehingga kemungkinan articaine lebih efektif terhadap bakteri aerob dibandingkan terhadap bakteri anaerob. Hal lain yang memungkinkan adalah perbedaan konsentrasi bahan yang digunakan. Kaya $\mathrm{K}$ menggunakan articaine dalam konsentrasi 0,007\%; $0,015 \% ; \quad 0,031 \% ; 0,062 \% ; \quad 0,125 \%$; $0,25 \%$; $0,5 \%$; dan $1 \%$ yang mana 
konsentrasi $1 \%$ terbukti yang paling efektif. Pada penelitian ini, peneliti menggunakan articaine $4 \%$ seseuai dengan konsentrasi yang digunakan dalam kedokteran gigi. Hal ini mungkin terjadi karena tidak selalu konsentrasi yang lebih tinggi memiliki efektifitas yang lebih tinggi pula. ${ }^{18}$

\section{KESIMPULAN}

Berdasarkan penelitian yang dilakukan oleh peneliti mengenai perbedaan daya hambat obat anestesi lokal lidocaine 2\% dan articaine $4 \%$ terhadap pertumbuhan bakteri Porphyromonas gingivalis secara in vitro didapatkan hasil sebagai berikut :

1. Obat anestesi lokal lidocaine $2 \%$ memiliki rata-rata daya hambat klasifikasi sedang terhadap pertumbuhan bakteri Porphyromonas gingivalis secara in vitro.

2. Obat anestesi lokal articaine $4 \%$ memiliki rata-rata daya hambat klasifikasi lemah terhadap pertumbuhan bakteri Porphyromonas gingivalis secara in vitro.

3. Terdapat perbedaan yang bermakna terhadap perbedaan daya hambat obat anestesi lokal lidocaine 2\% dan articaine $4 \%$ terhadap pertumbuhan bakteri Porphyromonas gingivalis secara in vitro. Lidocaine $2 \%$ lebih efektif dibanding articaine $4 \%$ dalam menghambat pertumbuhan bakteri Porphyromonas gingivalis secara in vitro.

\section{KEPUSTAKAAN}

1. Pedersen GW. Buku ajar praktis bedah mulut (Oral Surgery). 1st ed. Purwanto, Basoeseno, Alih bahasa; Yuwono L, editor. Jakarta : EGC. 1996. p. 83-100.

2. Riawan L. Penanggulangan Komplikasi Pencabutan Gigi. Makalah Pada Pembinaan Peningkatan Dokter Gigi Melalui Quality Assurance. Bandung : FKG UNPAD. 2002.

3. Li X, Kolltveit KM, Tronstad L, Olsen I. Systemic diseases caused by oral infection. Clin Microbiol Rev . 2000 Oct 1;13(4):547-58.

4. Heimdahl AN, Hall G, Hedberg M, Sandberg H, Söder PO, Tuner K, Nord CE. Detection and quantitation by lysisfiltration of bacteremia after different oral surgical procedures. J Clin Microbiol. 1990 Oct 1;28(10):2205-9.

5. Suzuki N, Yoneda M, Hirofuji T. Mixed red-complex bacterial infection in periodontitis. Int J Dent. 2013 Mar 6;2013.

6. da Silva-Boghossian CM, do Souto RM, Luiz RR, Colombo AP. Association Of Red Complex, A. Actinomycetemcomitans And Non-Oral Bacteria With Periodontal Diseases. Arc Oral Biol. 2011 Sep 30;56(9):899-906

7. Bhattacharya R, Xu F, Dong G, Li S, Tian C, Ponugoti B, Graves DT. Effect Of Bacteria On The Wound Healing Behavior Of Oral Epithelial Cells. PloS one. 2014 Feb 21;9(2):e89475.

8. Li L, Messas E, Batista EL, Levine RA, Amar S. Porphyromonas gingivalis infection accelerates the progression of atherosclerosis in a heterozygous apolipoprotein E-deficient murine model. Circulation. 2002 Feb 19;105(7):861-7.

9. Tong DC, Rothwell BR. Antibiotic prophylaxis in dentistry: a review and practice recommendations. J Am Dent Assoc. 2000 Mar 31;131(3):366-74.

10. Lockhart PB, Loven B, Brennan MT, Fox PC. The evidence base for the efficacy of antibiotic prophylaxis in dental practice. $\mathrm{J}$ Am Dent Assoc. 2007 Apr 30;138(4):45874.

11. Scarlett MI. Local Anesthesia in Today's Dental Practice. Provider. 2010;501:211886. 
12. Gmyrek R, Ratner D, Butler DF, Albertini JG, Quirk C, Elston DM. Local Anesthesia and Regional Anesthesia. Medscape : Updated Juli 07, 2015. URL http://www.emedicine.com/emerg/topic38 $\underline{3 . h t m}$

13. Ikhsan M, Mariati NW, Mintjelungan C. Gambaran Penggunaan Bahan Anestesi Lokal Untuk Pencabutan Gigi Tetap Oleh Dokter Gigi Di Kota Manado. e-GIGI. 2013;1(2).

14. Darawade DA, Kumar S, Budhiraja S, Mittal M, Mehta TN. A Clinical Study of Efficacy of 4\% Articaine Hydrochloride Versus 2\% Lignocaine Hydrochloride in Dentistry. Int J Oral Health : JIOH. 2014 Sep;6(5):81.

15. Kumar MS. Efficacy of Articaine over Lidocaine-A Review. J Pharm Sci \& Res Vol. 7(11), 2015, 956-959.

16. Malamed SF, Gagnon S, Leblanc D. A comparison between articaine $\mathrm{HCl}$ and lidocaine $\mathrm{HCl}$ in pediatric dental patients. Pediatrics Dent.. 2000 Jul;22(4):307-11.

17. Johnson SM, Saint John BE, Dine AP. Local Anesthetics As Antimicrobial Agents: A Review. Surgical infect. 2008 Apr 1;9(2):205-13.

18. Kaya K, Rota S, DOĞAN B, Kökten G, Günaydin B, Bozdayi G. Comparison of The Antibacterial Effects Of Two Local Anesthetics: Lidocaine And Articaine. Tr J Med Sci. 2007 Mar 14;37(1):7-10.

19. Bahl R. Local Anesthesia In Dentistry. Anesthesia progress. 2004;51(4):138.

20. Geoffrey L. Howe, F. Ivor, H. Whitehead, 1997. Anestesi Lokal. 3rd Ed. Jakarta : Hipokrates.

21. Mysak, J., Podzimek, S., Sommerova, P., Lyuya-Mi, Y., Bartova, J., Janatova, T., 2014, Porphyromonas gingivalis Major periodontopathic pathogen overview. J Immunol, 1-8.

22. Kusumawardani, B., Pujiastuti, P., Sandra D.S., 2010, Uji biokimiawi sistem API 20.

23. Coyle MB. Manual of antimicrobial susceptibility testing. American Society for Microbiol; 2005. 39-52.

24. Gilman AG, Rall TW, Nies AS, Taylor PG. Gilman's the pharmacological basis of therapeutics.

25. Dahlan, M. S. (2006), Besar Sampel Dalam Penelitian Kedokteran, Arkans, Jakarta: 19-70.

26. Mulyani Y, Bachtiar E, A Untung. Peranan Senyawa Metabolit Sekunder Tumbuhan Mangrove Terhadap Infeksi Bakteri Aeromonas hydrophila Pada Ikan Mas (Cyprinus carpio L.). J Akuatika. 2013 